\title{
КЛІНІКО-ФАРМАКОЛОГІЧНІ ОСОБЛИВОСТІ ВИКОРИСТАННЯ АНТАГОНІСТІВ АЛЬДОСТЕРОНУ У ХВОРИХ $З$ ГІПЕРТОНІЧНОЮ ХВОРОБОЮ
}

\author{
МОЙСЕЄНКО В.О., БОНДУР В.В., ЛЮБИЦЬКИЙ А.О.
}

\author{
Національний медичний університет імені О.О. Богомольця \\ Київ, Україна
}

\section{Резюме}

Ключові слова:

Вступ. Гіпертонічна хвороба - надпоширене захворювання з тенденцією до щорічного росту. Вона призводить до великої кількості морбідних станів, має багато проявів та викликає численні ускладнення. 3 метою їі лікування продовжують розроблятися та впроваджуватися нові фармакологічні препарати які попереджають швидке прогресування захворювання, мають кращий профіль безпеки, а також не погіршують якість життя пацієнтів. Гіпотензивна активність, переносимість при тривалому застосуванні та цінова доступність антигіпертензивних препаратів продовжують залишатися визначальними при обранні конкретної фармакотерапії.

Мета. Порівняти ефективність, безпечність та особливості фармакологічної дії при застосуванні антигіпертензивних препаратів спіронолактону та еплеренону.

Матеріали та методи. Бібліографічний - проведено теоретичний аналіз та здійснено узагальнення даних літератури, проаналізовано фактичний вміст. При дослідженні використано анкетно-опитувальний метод, а також - опис, аналіз, реферування.

Результати та їх обговорення. Велику увагу клініцистів останнім часом привертають сечогінні препарати з групи антагоністів альдостерону у зв'язку з їх достатньою діуретичною активністю та високою безпечністю. Препаратом нового покоління слід вважати еплеренон, який проявляє свою ефективність та безпечність не лише при лікуванні артеріальної гіпертензії, а й у випадку інших захворювань - альбумінурії при цукровому діабеті II типу, хронічної хвороби нирок та при гіперальдостеронізмі. Фармакологічні властивості еплеренону наділили його більшою специфічністю до блокування рецепторів мінералокортикоїдів. При лікуванні артеріальної гіпертензії еплеренон не поступався у антигіпертензивній активності своєму попереднику із цієї фармакологічної групи - спіронолактону, проте рідше викликає певні небажані ефекти, які часто зустрічаються при його застосуванні.

Висновки. Еплеренон безпечніший від свого попередника - спіронолактона, має високу ефективність, що дає можливість внести цей препарат у лінію фармакологічних засобів для лікування хвороб, описаних в даній статті.

артеріальна гіпертензія, резистентна артеріальна гіпертензія, хронічна хвороба нирок, швидкість клубочкової фільтрації, спіронолактон, еплеренон.
Вступ. За результатами досліджень 2010 року у всьому світі зареєстровано вже 1.38 млрд. випадків артеріальної гіпертензії (31.1\% дорослого населення) [2]. Дослідження також показали що є певна різниця у схильності окремих етнічних груп, народів та країн до розвитку артеріальної гіпертензії їх жителів. Наприклад, вищий систолічний артеріальний тиск було виявлено у жителів південної Азії, суб-Сахарської території Африки, центральної та східної Європи [2]. У дослідженні брали участь 8.69 млн. учасників у 154 країнах світу, тому його можна вважати достовірним стосовно широкої вибірки [2]. Також останніми десятиліттями спостерігається стабілізація або невелике зменшення розрахункового середнього систолічного та діастолічного ар- теріального тиску у високорозвинених країнах, а у слаборозвинених та тих що розвиваються поширеність артеріальної гіпертензії неухильно зростає [2]. Так в Україні, станом на 1 січня 2011 року МОЗ було зареєстровано 12122512 випадків, що становило $32.2 \%$ дорослого населення, що вдвічі перевищувало результат 1998 року [3]. Робочою групою з артеріальної гіпертензії асоціації кардіологів (серед них проф. Свіщенко Є.П., проф. Багрій А.Е., проф. Єна Л.М., проф. Коваль C.M. та інші) було показано, що серед міського населення поширеність артеріальної гіпертензії складає 29.6\%, серед них усвідомлюють свій діагноз 80.8\%, лікуються 48.4\%, а ефективність лікування складає $18.7 \%$. У сільській місцевості відсоток населення, що знають про наявну хво- 
робу складає 67.8\%, з них лікуються 38.3\%, а ефективність лікування становить 8.1\% [3]. Серед патологічних факторів що впливають на формування гіпертонічної хвороби частіше всього виявляють: ожиріння, дієта багата на натрій і бідна на калій (вживання в їжу багато кухонної солі), малорухливий спосіб життя, зловживання алкоголем, тютюнопаління, стресові ситуації, чоловіча стать, вік (для чоловіків >55 років, для жінок >65 років) [1]. Тенденціями сучасного світу $є$ зростання розповсюдженості та тривалості дистанційної роботи через інтернет, сидячого способу життя в офісах та навчальних закладах. Недостатність часу змушує людей вести неправильний, з точки зору здоров'я, ритм життя недосипання, стрес, шкідливі звички, використання послуг фаст фуду. Існують небезпідставні переконання, що в майбутньому епідеміологія артеріальної гіпертензії може ще більш погіршитися, що призведе до збільшення економічних витрат населення та держав для боротьби з цією проблемою. Тому для вирішення та/або мінімізації проблеми артеріальної гіпертензії продовжують розроблятися та впроваджуватися нові антигіпертензивні препарати: блокатори кальцієвих каналів (БКК), $\beta$-адреноблокатори, інгібітори АПФ (і-АПФ), блокатори рецепторів ангіотензину II типу (БРА2) діуретики різного походження та інші. [20]. Одним з компонентів антигіпертензивної терапії, який позитивно зарекомендував себе за час спостережень, став калій-зберігаючий діуретик, блокатор рецепторів альдостерону - спіронолактон, який було відкрито в 1957 році та введено в обіг у 1959 році. Незважаючи на солідний термін існування на фармацевтичному ринку препарат не втрачає своєї актуальності і донині. Він присутній у переліку основних лікарських засобів В003, в категорії ліків, необхідних в системі охорони здоров'я. Оптова ціна на упаковку препарату в світі, станом на 2014 рік складає від 0.02 до 0.12 доларів США в день. У Сполучених Штатах він коштує близько 0.50 доларів на день в середній терапевтичній дозі.

У крупному дослідженні RALES (1999), в якому приймало участь 1663 пацієнта з 15 країн, було виявлено, що спіронолактон у складі комбінованої терапії знижував ризик смерті, пов'язаної з серцево-судинними порушеннями, на $31 \%$, порівнюючи з групою пацієнтів, яким призначалось плацебо (у складі оптимальної фармакотерапії) [19, 21]. 3 часу визнання цього препарату як ефективного засобу для пацієнтів з артеріальною гіпертензією, первинним гіперальдостеронізмом, серцевою недостатністю та зменшенням лівошлуночкової фракції викиду нижче 40\%, спіронолактон тривалий час знаходиться у рекомендаціях по лікуванню захначених станів [4, 9, 19, 20, 21]. Однак через наявність тяжких небажаних побічних ефектів спіронолак- тону, зокрема високої антиандрогенної активності, досить часто виникає необхідність у заміні цього препарату. Одним із препаратів вибору на сьогоднішній день $€$ сучасний антагоніст альдостерону - еплеренон, що має стероїдну будову, та $€$ 9, 11-а епокси-дериватом першого представника цієї групи - спіронолактону. Еплеренон був розроблений шведською фірмою «Pharmacia Corporation», яку пізніше придбала американська корпорація «Pfizer» та продовжила подальшу розробку і маркетинг препарату. Еплеренон був схвалений FDA для клінічного застосування у США у 2002 році, а згодом дозволений до використання у Японії та Європейському Союзі.

Мета. Порівняти показники ефективності, безпечності, специфіку застосування, показання та протипоказання спіронолактону та еплеренонy.

Матеріали і методи. Бібліографічний - проведено теоретичний аналіз та здійснено узагальнення даних літератури, проаналізовано фактичний вміст. При дослідженні використано анкетно-опитувальний метод, а також - опис, аналіз, реферування.

Результати та їх обговорення. Спіронолактон - це антагоніст альдостерону, який конкурентно зв'язується з альдостерон - залежними рецепторами $\mathrm{Na+-K+-обмінних} \mathrm{каналів} \mathrm{у} \mathrm{дис-}$ тальних звивистих канальцях та чинить свою діуретичну дію екскретуючи $\mathrm{Na}+$ та $\mathrm{Cl}-$, при цьому зменшуючи виведення K+ [5]. При станах, за яких концентрація альдостерону в плазмі крові підвищена, наприклад при первинному та вторинному гіперальдостеронізмі, спіронолактон входить в обійму препаратів першої лінії для пацієнтів із зазначеною патологією. Конкуруючи за місця зв'язування з альдостероном, спіронолактон справляє терапевтичний ефект при набряках, асциті та інших вищезгаданих станах [5].

Середній час, за який спіронолактон та його активний метаболіт досягає максимальної концентрації в плазмі крові, складає 2.6 та 4.3 години відповідно. Біодоступність становить $90 \%$, а період напіввиведення досягає 1.4 години (його активних метаболітів канренону, 7- $\alpha$-спіронолактону та 6- $\beta$-гідрокси-7$\alpha$-спіронолактону - відповідно $16.5,13.8$ та 15 годин) [5]. Виводяться спіронолактон та його активні метаболіти переважно із сечею та частково з жовчю [5].

Одним з найістотніших побічних ефектів після антиандрогенної дії слід назвати вплив на обмін калію. Дослідженням RALES (Randomized Aldoctone Evaluation Study; альдактон=спіронолактон), що включало в себе 551 пацієнта, яким було призначено спіронолактон та проводилися регулярні лабораторні тести, було зафіксовано, що у $15 \%$ пацієнтів розвивалась гіперкаліємія (>5.5ммоль/л), а у 6\% пацієнтів розвивалась важка гіперкаліє- 
мія (>6ммоль/л) [4]. Гіперкаліємія також була виявлена у тих хто приймав препарати з вмістом калію та у дієті яких мали місце продукти з високим вмістом калію [4]. Широкий мета-аналіз був проведений у 2016 році для оцінки клінічної ефективності спіронолактону у пацієнтів з резистентною гіпертензією [21, 22]. В нього входили 5 досліджень, в яких підсумовувались результати, отримані у 270 пацієнтів, які проходили чотирьох компонентну антигіпертензивну терапію з використанням спіронолактону. Дослідники звітували про наступні основні показники - зміни АТ впродовж дня та рівень сироваткового калію [21, 22]. Сумуючи результати досліджень, показано, що спіронолактон знижував середнє добове значення САТ на 10 мм.рт.ст. та ДАТ на 4.5 мм.рт.ст. більше ніж у групі плацебо [21, 22]. Доза спіронолактона в усіх дослідженнях була $\leq 50$ мг/добу, тому випадки серйозної гіперкаліємії були відносно низькими та коливались від $1.2 \%$ до 7.5\%.

3 боку ШКТ було повідомлено про випадки виразкоутворень та асоційованих з ними кровотеч. В Нідерланадах у дослідженні з 306645 учасників, яких розділили на 10 груп за віком і статтю $[4,6]$, встановлено, що у 523 з 5230 осіб відмічалось виразкоутворення або шлунково-кишкова кровотеча. Використання спіронолактону пов'язували зі збільшеним у 2.7 разів ризиком розвитку одного з вищеназваних наслідків з боку ШКT $[4,6]$.

Як уже відмічалось, спіронолактон, окрім рецепторів альдостерону, також пригнічує тестостеронові рецептори, через що має антиандрогенні властивості. Для порівняння - еплеренон виявляє в 370 разів меншу активність у блокуванні рецепторів активації дигідротестостерону $[4,8]$. У жінок з гірсутизмом нез'ясованої етіології на тлі синдрому полікістозних яєчників, яким призначали спіронолактон, було відмічено зниження рівня тестостерону, Прийом спіронолактону пов'язують з появою болючої гінекомастії, зменшення лібідо та розвитком еректильної дисфункції у 4-30\% чоловіків [4]. У жінок спостерігається збільшення та болючість молочної залози разом з розладами менструального циклу, що також було пов'язане з прийомом спіронолактону. Вживання 400 мг/добу приводило до порушень циклу, а 100-200 мг/день - до аменореї [4].

У ретроспективному когортному дослідженні, яке проводилось у 88 пацієнтів (у 34 з яких були наявні хронічні захворювання нирок - швидкість клубочкової фільтрації <45 мл/хв) пацієнтам було призначено прийом спіронолактону у дозі 12.5-25 мг/добу. На тлі цього відмічалось збільшення концентрації калію в плазмі крові на 0.5 ммоль/л у хворих з хронічною хворобою нирок та збільшення на 0.3 ммоль/л у хворих з нормальною функцією нирок. Дослідження показа- ло, що знижена швидкість клубочкової фільтрації (<45 мл/хв) сприяє розвитку синдрому гіперкаліємії [7]. Що до впливу на обмін холестерину, тригліцеридів та ЛПВЩ з ЛПНЩ, то у різних дослідженнях отримано неоднозначні результати [4].

Наостанок виділимо протипоказання для застосування спіронолактону: анурія, гостра ниркова недостатність, значне порушення екскреторної функції нирок та гіперкаліємія [9].

Ринок препаратів спіронолактону в Україні заповнюють продукти фармакологічних компаній Gedeon Richter (Угорщина) VEROSPIRON, Darnitsa PrJSC (Київ, Україна) - SPIRONOLACTONUM-DARNITSA Ta Sandoz (Швейцарія) - SPIRONOLACTON SANDOZ. Серед пропонованих виробниками доз та розмірів упаковок препаратів спіронолактону ситуація має наступний вигляд. Компанія Gedeon Richter випускає препарат у дозі 25 мг № 20 та по 50 мг і 100 мг № 30. Darnitsa PrJSC пропонує кількість діючої речовини по 25 мг та 100 мг по 30 таб. в упаковці. Sandoz випускає свій продукт у двох форматах - 50 мг № 30 та 100 мг № 30. За доступними інформаційними джерелами обіг усіх упаковок спіронолактону на ринку фармакологічних препаратів України у 2020 році складав кількість близьку до 3 млн одиниць. При цьому на частку упаковок препарату виробництва Gedeon Richter приходилось приблизно понад 46 \% ринкової частки, Darnitsa PrJSC та Sandoz мали приблизно однакову частку. Роздрібні ціни на продукцію представлені наступим чином. Упаковка 25 мг, 20 таб. від Gedeon Richter коштувала приблизно 33 грн, а від Darnitsa PrJSC по 25 мг, 30 таб. - 45.5 грн. Упаковка спірінолактону по 50 мг 30 таб. від Gedeon Richter коштувала понад 125 грн. I нарешті 30 таб. по 100 мг спірінолактону виробництва Gedeon Richter коштувала близько 175 грн; від Darnitsa PrJSC - 101.68 грн, а препарат Sandoz можна було придбати за 99.48 грн.

Еплеренон - похідне спіронолактону, а точніше - дериват епокси-спіронолактону $(9,11$ - епокси - група в лактонному кільці) [13]. Вагомою рисою епокси - групи є значно нижча (у 370 разів), здатність до блокування рецепторів дигідротестостерону, за рахунок чого низькі терапевтичні дози еплеренону не пов'язують з виникненням гінекомастії у чоловіків та інших небажаних побічних ефектів з боку статевої системи. Також, за рахунок епокси- груп, еплеренон менш афінний до рецепторів глюкокортикоїдів та прогестерону $[11,12,13]$. І хоча еплеренон у $15-20$ разів менш афінний до мінералокортикоїдних рецепторів, “міліграм-міліграм" еплеренону прирівнюють до спіронолактону за ефективністю. При цьому, зростання концентрації реніну та альдостерону в плазмі не впливає на показники АT, адже рецептор альдостерону в даному випадку надійно заблокований [13]. 
Фармакокінетика еплеренону проходить по однокомпонентному шляху. 3 нього не утворюється активні метаболіти, а їжа не гальмує всмоктування в ШКТ, як у випадку спіронолактону [13]. Біодоступність складає приблизно $69 \%$, середня пікова концентрація препарату у плазмі крові досягається впродовж 2 годин після прийому, а стабільний рівень в сироватці крові встановлюється на протязі двох днів [14]. Приблизно 49\% еплеренону зв'язується з білками плазми крові, що поліпшує доставку речовини до рецепторів альдостерону. Деактивується в печінці за рахунок СYР3А4 і екскретується 3 організму 5\% у незміненому вигляді, а інша частина у вигляді неактивних метаболітів, 66\% з сечею та $\sim 32 \%$ з калом [13]. Слід наголосити, що окремі препарати здатні порушувати фармакокінетику еплеренону, зокрема інгібітори CYP3А4 (еритроміцин, кларитроміцин, флуконазол, верапаміл, кетоконазол та інш.) [10, 11, 12, 13].

На основі EMPHASIS-HF було проведено дослідження, стосовно ризиків розвитку гіперкаліємії [27]. До заздалегідь визначеної підгрупи ризику входили: пацієнти > 75 років, хворі на діабет I типу, хронічну ниркову хворобу (швидкість клубочкової фільтрації <60 мл/хв/1.73м2) та САТ < 123 мм.рт.ст. на момент початку дослідження [27]. Концентрацію К+ контролювали при першому візиті пацієнта, через тиждень і потім кожні 4 тижні до останнього візиту [27]. Показанням до зниження дози була концентрація калію в межах 5.5-5.9 ммоль/л, а відміна препарату наступала у випадку концентрації у понад 6.0 ммоль/л; також повідомлялось про тяжкі побічні ефекти, такі як госпіталізація з приводу гіперкаліємії, смерть чи госпіталізація від серцевої недостатності або погіршення ниркової функції [27]. Впродовж дослідження, було зареєстровано 188 (13.8\%) відмін препарату в групі еплеренона та 222 (16.2\%) в групі плацебо у зв'язку з побічними ефектами. В кожній з названих груп ризику частота відміни досліджуваного препарату та плацебо, у зв'язку з побічними ефектами, значно не відрізнялась і складала в середньому 17-18\% [27]. В групі хворих на хронічну хворобу нирок 70 із 436 (16.1\%) пацієнтам у групі еплеренону та 105 із 471 (22.3\%) в групі плацебо виникла потреба у відміні препарату через побічні ефекти [27]. Сумарно, співвідношення користь/ризик у пацієнтів з високим ризиком розвитку гіперкаліємії говорить про значну безпеку еплеренону за умови суворого контролю рівня калію [27]. Стосовно впливу еплеренону на ниркову фільтрацію проводилось подвійно-сліпе, рандомізоване, плацебо контрольоване дослідження [26]. В ньому - чоловіки і жінки $з$ діабетом другого типу та співвідношенням альбуміну до креатиніну у сечі $(\mathrm{AKC}) \geq 50$ мг/г (пацієнти з гіпертензією в анамнезі були наявні, але їх АТ<180/110, а сироватковий калій знаходився в межах від 3.5 до 5.0 ммоль/л) [26]. У дослідженні не приймали участь пацієнти, в анамнезі яких були наявні загрозливі захворювання серцево-судинної системи: особи, які перенесли інфаркт, а також хворі з неконтрольованою стенокардією чи аритмією [26]. Пацієнтів розділили на 3 групи: перша (I) отримувала еналапріл 20 мг/ добу та еплеренон 50 мг/добу, друга (II) еналапріл 20 мг/добу та еплеренон 100 мг/добу та третя (III) еналапріл 20 мг/добу + плацебо [26]. 87\% з 268 пацієнтів пройшли повний курс лікування, що складав 12 тижнів [26]. Результатами дослідження встановлено значне зменшення АKC більше 40\% у I групі та 50\% у II групі, у III групі зменшення було менше 10\%. У пацієнтів з ШКФ>70 мл/ хв/1.73м2 АКС знижувався на 51-62\%, у пацієнтів з ШКФ<70 мл/хв/1.73м2 АКС знижувався на $42-48 \%$ [26].

Фармакокінетика еплеренону досліджувалась у хворих з серйозними порушеннями ниркових функцій та в осіб, що проходили курс гемодіалізу. У перших препарат затримувався в організмі довше на 38\%, а пікова плазмова концентрація наступала швидше на 24\% . У хворих, які підлягали гемодіалізу, препарат виводився на $26 \%$ швидше, проте гемодіаліз на час настання пікової плазмової концентрації практично не впливав [14]

Досліджуючи довгостроковий вплив еплеренону на діуретичні показники у пацієнтів з хронічною нирковою хворобою, дослідники відібрали пацієнтів, що відвідували ниркове відділення університетської клініки Кейо, Токіо [25]. Критеріями відбору хворих для дослідження були: рівень сироваткового альдостерону > 15 нг/дл, а концентрація К+ менше 5.5 ммоль/л. 20 із 22 пацієнтів пройшли повний курс лікування еплереноном в дозі по 25 мг/добу впродовж 3 років. Одному 3 них довелось призупинити прийом еплеренону у зв'язку з діабетом I типу, а інший пацієнт припинив застосування препарату за власним бажанням [25]. В групі плацебо пройшли повний курс 19 із 26 пацієнтів. 1 пацієнт вибув з дослідження через виявлення карциноми простати, 1 - через карциному товстої кишки, 1 - через інфаркт мозку, 1 - через гіпофункцію гіпофіза і 2 відмовились самостійно. Протягом дослідження було виявлено, що в групі еплеренону концентрація сироваткового альдостерону коливалась з 21.6 до 25.7 нг/дл, а в групі плацебо від 18.9 до 19.3 нг/дл. АКС в сечі значно знизилось в групі еплеренону в перші 6 місяців з 0.47 до 0.32 і станом на 36-ий місяць дослідження становило 0.29, а в групі плацебо протягом 36 місяців трималося в межах 0.42, а під кінець дослідження складало 0.48 [25]. Співвідношення сечового $\alpha$-1-мікроглобуліну/креатиніну - маркер ураження трубочок значно, знизився в групі 
еплеренону і залишався нижче значення групи плацебо до кінця дослідження (8.72 на початку і 6.1 через 36 місяців у групі еплеренону) [25]. ШКФ в групі еплеренону за 36 місяців змінився

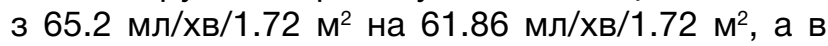
групі плацебо з 63.95 мл/хв/1.72 м2 до 54.62 мл/ $\mathrm{xв} / 1.72 \mathrm{~m}^{2}$ [25].

Якщо розглянути плазмове співвідношення альдостерон/ренін до ШКФ, то буде зрозуміло, що на кінцевих стадіях хронічної ниркової хвороби це співвідношення різко піднімається (збільшується концентрація альдостерону в плазмі), а ШКФ знижується з 60 мл/хв/1.72 м² до 15 мл/ Хв/1.72 $\mathrm{M}^{2}$ [29].

У пацієнтів, які проходили курс гемодіалізу, та яким був показаний прийом блокаторів мінералокортикоїдних рецепторів, лише у обмеженому числі випадків виявлялись серйозні клінічні прояви гіперкаліємії [29]. Еплеренон у малих терапевтичних дозах сприяє поліпшенню стану пацієнтів з термінальними стадіями хронічної хвороби нирок [29, 30].

Щодо клінічної ефективності препарату, фармакотерапія еплереноном була досліджена у двох великих рандомізованих дослідженнях EPHESUS та EMPHASIS [15, 16]. У дослідженні приймали участь пацієнти після інфаркту (314 діб), пост-інфарктним симптомом зниженого ліво-шлуночкового серцевого викиду $<40 \%$ та серцевою недостатністю [15, 16]. Встановлено, що в групі еплеренону за час проведення дослідження, померлих від серцево-судинних порушень було 10.8\%, а в групі плацебо - 13.5\%, від числа усіх померлих [16]. Ризик гіперкаліємії в групі хворих які приймали еплеренон був 5.5\%, а в групі плацебо 3.9\% [15]. У результатах дослідження вказано, що ризик госпіталізації за серцево-судинними показаннями та смерті від кардіальних та судинних ускладнень в групі пацієнтів, які застосовували еплеренон був статистично нижчим $[15,16]$.

За результатами ще кількох репрезентативних досліджень, еплеренон показав більшу ефективність у зменшенні систолічного (САT) та діастолічного (ДАТ) артеріального тиску порівняно з препаратами інших груп $[12,13,17,18]$. Так у дослідженні, де брали участь дві групи пацієнтів (еплеренон та плацебо), відмічено, що призначення еплеронону сприяє зниженню САТ в середньому на 9,21 мм.рт.ст. та діастолічного на 4,18 мм.рт.ст., порівняно з групою плацебо [17]. Франческо Пеліціа, разом з співробітниками, у 2014 році відібрали найбільш репрезентабельні клінічні дослідження використання еплеренону у порівнянні з іншими лікарськими препаратами. Дослідження відбирались за наступними критеріями: діагноз пацієнта (легка або помірна артеріальна гіпертензія; резистентна та вторинна гіпертензія були вилучені), їх характер (рандо- мізовані, контрольовані впродовж щонайменше 4-х тижнів з постійним моніторингом) та наявність обов'язкових параметрів (рівень АТ, причин відміни препарату, побічних ефектів та випадків загрозливих кардіоваскулярних станів) [18]. У шести дослідженнях, в яких загалом приймали участь 1827 пацієнтів, еплеренон в середньому знижував САТ на 8.07 мм.рт.ст. та ДАТ на 4.08 мм.рт.ст. більше ніж в групі плацебо [18].

Крім того, відповідно до даного дослідження, порівнюючи з іншими антигіпертензивними препаратами, еплеренон знижував показники САТ і ДАТ наступним чином. Порівняно з лозартаном, зниження САТ фіксувалось на 6.24 мм.рт.ст більше, а з еналаприлом - всього на 1.63 мм.рт.ст. Спіронолактон виявився ефективнішим за еплеренон у зниженні САТ (на 6.4 мм.рт.ст.) та ДАТ (на 3.1 мм.рт.ст.) $[17,18]$ Середнє зниження ДАТ було більше на користь спіронолактона на 3.1 мм.рт. ст., на 0.34 мм.рт.ст. більше знижував еналаприл, але еплеренон більш ефективніше (в середньому на 3.2 мм.рт.ст.) знижував ДАТ у порівнянні 3 лозартаном. Застосовуючи еплеренон у якості монотерапії, вдавалося досягти зниження САТ на 6-13 мм.рт.ст. та ДАТ на 3-7 мм.рт.ст. [10]. Стосовно безпеки терапії, застосування еплеренонну викликало співставимий об'єм побічних ефектів, як і при призначенні інших антигіпертензивних препаратів [17, 18]. Незважаючи на проведення запобіжних гіперкаліємії заходів, таких як постійний моніторинг сироваткового К+, інформування пацієнтів та призначення дієти низької на $\mathrm{K}+$, ризик гіперкаліємії залишався досить вагомим у випадку застосування калій-зберігаючих діуретиків.

Виходячи 3 результатів дослідження EMPHASIS-HF, у пацієнтів з серцевою недостатністю та серцевим викидом $<40 \%$, еплеренон ефективно знижував співвідношення смертності від серцево-судинних ускладнень та госпіталізацій за показаннями серцевої недостатності на $37 \%$, а також смерть від усіх можливих причин на 24\%, порівняно з групою плацебо протягом 21 місяця спостереження [28]. У дослідженні EPHESUS, у пост-інфарктних пацієнтів з ліво-шлуночковою та серцевою недостатністю або діабетом, еплеренон знижував співвідношення смертності від серцевосудинних подій до госпіталізацій за показаннями серцевої недостатності на 13\% і смертність від усіх можливих причин на 15\% [28]. За результатами цього дослідження, у типового 60-річного пацієнта, з групи еплеренону, не спостерігалося небажаних серцево-судинних подій на 1.2 років більше, порівняно з групою плацебо [28]. У іншому дослідженні брали участь 66 пацієнтів з резистентною АГ (РАГ) та додатковими коморбідними станами, які проходили курси лікування відповідно до всесвітніх рекомендацій [32]. Пацієнтам призначили фіксовану трикомпонентну комбінацію, що складалася з блокатора ренін- 
ангіотензин-альдостеронової системи/діуретика/ БKК із додаванням додаткових препаратів, спочатку, спіронолактону (середня доза 45 мг/добу), еплеренону (середня доза 48 мг/добу), небівололу (середня доза 9 мг/добу) та моксонідину (середня доза 0.5 мг/добу) [32]. Препарати додаткової фармакотерапії змінювали кожні 3 місяці [32]. 63 з 66 пацієнтів пройшли повний курс - 1 пацієнт вибув через нагрубання молочних залоз на тлі застосування спіронолактону, 1 пацієнт вибув через значне зменшення ЧСС на тлі використання небівололу та 1 від сухості та набрякання слизової оболонки носа при використання моксонідину [32]. Результати виявились наступними: САТ, при вхідному значенні 153.6 мм.рт.ст. знизився у групах спіронолактону на 17.9 мм.рт.ст., еплеренону на 17.5 мм.рт.ст., небівололу на 12.5 мм.рт.ст. та моксонідину на 13.2 мм.рт.ст. [32]. Показники ДАТ, який від початку дослідження становив 87 мм.рт. ст. знизився у групі спіронолактону на 5.2 мм.рт. ст., еплеренону на 7.9 мм.рт.ст., небівололу на 6.7 мм.рт.ст. та моксонідину на 4.3 мм.рт.ст. [32]. По завершенню дослідження, цільового значення АТ вдалося досягти 68.2\% пацієнтів з групи спіронолактону, 65.2\% пацієнтів в групі еплеренону, $53.9 \%$ пацієнтів з групи небівололу та 56.2\% - у пацієнтів, які приймали моксонідин [32].

Стососно доступності фармакотерапії еплереноном в Україні то слід зазначити, що ринок цього препарату в Україні представлений достатнім розмаїттям фармацевтичних компаній-виробників у кількості діючої речовини по 25 мг та 50 мг. Загальний продаж упаковок еплеренону, за сукупними даними 2020/21 років складав понад 430 тис одиниць щорічно.

Лідером за продажами у зазначений період був препарат EPLETOR від Borschagovsky ChPhP PJSC (Київ, Україна) з ринковою часткою у понад $35 \%$.

До основних виробників еплеренону в Україні відносяться компанія Arterium Corporation OJSC (Київ) з препаратом RENIAL та Kyiv Vitamin Plant JSCo (препарат EPLEPRES). На ринку представлений і оригінатор еплеренону - французський виробник Fareva Ambroise (препарат INSPRA), розповсюдженням якого займалася Pfizer Inc, а також постачальники генеричних засобів з незначною ринковою долею. Порівнюючи вартість препаратів спірінолактону та еплеренону у еквівалентих доза за аналогічними показаннями слід зазначити, що середня вартість лікування за місяць від лідерів продаж для спірінолактону становила близько 50 грн, а еплеренону 420 грн. Однак, незважаючи на таку фармакоекономічну невідповідність у вартості лікування слід пам'ятати про суттєву безпечність використання еплеренону, що повинен брати до уваги лікар, призначаючи відповідну фармакотерапію.
Висновки. Виходячи з описаних досліджень та їх результатів можна стверджувати про достатньо високу безпечність застосування еплеренону. Еплеренон, маючи меншу афінність до мінералокортикоїдних рецепторів, може мати нижчий антигіпертензивний ефект, проте в перспективі “міліграм-міліграм", не було помічено суттєвої різниці у зниженні АД при порівнянні еплеренону та спіронолактону. Проте з огляду на практичну відсутність таких побічних ефектів, як болюча гінекомастія, зниження лібідо та порушення еректильної функції у чоловіків, а також розлади менструального циклу у жінок, еплеренон має суттєві переваги над спіронолактоном. Найголовніше застереження, про яке варто пам'ятати лікарям - це розвиток гіперкаліємії (підвищення концентраціі K+ в плазмі крові >5.5 ммоль/л). Однак, гіперкаліємія може бути контрольована додаванням до фармакотерапії тіазидного діуретика. Еплеренон може знайти собі застосування при лікуванні не тільки гіпертонії, проте також у ряді наступних станів - у постінфарктних пацієнтів зі зниженою фракцією викиду лівого шлуночка (ejection fraction<40\%), при серцевій недостатності та у пацієнтів з альбумінурією, хронічною хворобою нирок та первинним гіперальдостеронізмом. Еплеренон як у форматі монотерапії, так і в комбінації з іншими препаратами здатен нормалізувати ниркову фільтрацію та захистити нирковий апарат протягом тривалого часу. Також еплеренон пов'язують із значним подовженням тривалості життя у пацієнтів із зазначеними патологіями.

Перспективи. Суттєва відносна безпечність еплеренону $є$ важливим фактором вибору препарату, що переважає економічні затрати на лікування, особливо у пацієнтів репродуктивного віку. Присутність на ринку достатнього кола виробників препаратів з групи антагоністів альдостерону дозволяє забезпечувати потреби пацієнтів у якісних і доступних ліках.

\section{ЛITEPATУPA}

1. https://compendium.com.ua/uk/tutorials-uk/ vnutrishnya-meditsina/2-rozdil-zakhvoriuvanniasertsia-ta-sudyn/2-3-gipertonichna-hvoroba/

2. Mills K. T., Stefanescu A., \& He J. (2020). The global epidemiology of hypertension. Nature Reviews Nephrology. doi:10.1038/s41581019-0244-2

3. https://www.dec.gov.ua/wp-content/uploads/2019/11/384_2012_kn_ag.pdf

4. https://doi.org/10.1016/B978-0-444-537171.01466-9

5. https://www.pfizermedicalinformation.com/enus/aldactone/clinical-pharmacology 
6. Verhamme K., Mosis G., Dieleman J., Stricker B., Sturkenboom M. Spironolactone and risk of upper gastroinsestinal events: populatione-based case-control study. BMJ 2006; 333(7566): 501.

7. Jodi Heshka, MDa, Marcel Ruzicka, MD, PhDa,b,c, Swapnil Hiremath, MD, MPHa,b,c, and Brendan B. McCormick, MD. Journal of American Society of Hypertension 4(6) (2010) 295-301.

8. Susan M. Garthwaite, Ellen G. Mcmahon. The evolution of aldosterone antagonists. Molecular and Cellular Endocrinology 217 (2004) 27-31.

9. Aldactone (Spironolactone). U.S. Food and Drug Administration (FDA).

10. Inspra (Eplerenone). U.S. Food and Drug Administration (FDA).

11. Furman B.L. Eplerenone. Strathclyde Institute of Pharmacy and Biomedical Sciences, Glasgow, United Kingdom. Elsevier. (2017)

12. Andrew J. Stewart Coats, Louise Shewa, Eplerenone's role in the management of complex cardiovascular disorders, International Journal of Cardiology, 2015.

13. James AS Muldowney III, John A Schoenhard \& Cassandra $D$ Benge. The clinical pharmacology of eplerenone. Expert Opin. Drug Metab. Toxicol. (2009) 5(4):425-432.

14. https://www.pfizermedicalinformation.com/enus/eplerenone/clinical-pharmacology

15. Bertram Pitt, M.D., Willem Remme, M.D., Faiez Zannad, M.D., James Neaton, Ph.D., Felipe Martinez, M.D., Barbara Roniker, M.D., Richard Bittman, Ph.D., Steve Hurley, B.S., Jay Kleiman, M.D., and Marjorie Gatlin, M.D. Eplerenone, a Selective Aldosterone Blocker, in Patients with Left Ventricular Dysfunction after Myocardial Infarction. The new england journal of medicine. 2003

16. Faiez Zannad, M.D., Ph.D., John J.V. McMurray, M.D., Henry Krum, M.B., Ph.D., Dirk J. van Veldhuisen, M.D., Ph.D., Karl Swedberg, M.D., Ph.D., Harry Shi, M.S., John Vincent, M.B., Ph.D., Stuart J. Pocock, Ph.D., and Bertram Pitt, M.D., for the EMPHASISHF Study Group. Eplerenone in Patients with Systolic Heart Failure and Mild Symptoms. The new england journal of medicine. 2011

17. Tam TSC, Wu MHY, Masson SC, Tsang MP, Stabler SN, Kinkade A, Tung A, Tejani $A M$. Eplerenone for hypertension. Cochrane Database of Systematic Reviews 2017, Issue 2. Art. No.: CD008996.

18. Francesco Pelliccia, Giuseppe Patti, Giuseppe Rosano, Cesare Greco, Carlo Gaudio. Efficacy and safety of eplerenone in the management of mild to moderate arterial hypertension: Systematic review and metaanalysis. International Journal of Cardiology 177, 219-228. 2014

19. Подзолков В.И., Драгомирецкая Н.A. Антагонисты альдостерона. Современные представления о механизмах действия и эффектах спиронолактона. Рациональная Фармакотерапия в Кардиологии 2017; 13 (2): 263-269. DOI: http://dx.doi. org/10.20996/1819-6446-2017-13-2-263-269

20. Thomas Unger, Claudio Borghi, Fadi Charchar, Nadia A. Khan, Neil R. Poulter, Dorairaj Prabhakaran, Agustin Ramirez, Markus Schlaich, George S. Stergiou, Maciej Tomaszewski, Richard D. Wainford, Bryan Williams, Aletta E. Schutte 2020 International Society of Hypertension Global Hypertension Practice Guidelines DOI: 10.1161/ HYPERTENSIONAHA.120.15026

21. Bertram Pitt, M.D., Faiez Zannad, M.D., Willem J. Remme, M.D., Robert Cody, M.D., Alain Castaigne, M.D., Alfonso Perez, M.D., Jolie Palensky, M.S., And Janet Wittes, Ph.D. The effect of spironolactone on morbidity and mortality in patients with severe heart failure. The New England Journal of Medicine. September 2, 1999

22. Chunbin Wang, MD, Bo Xiong, MD, Jing Huang, $M D$. Efficacy and Safety of Spironolactone in Patients with Resistant Hypertension: A Metaanalysis of Randomised Controlled Trials. Heart, Lung and Circulation (2016) xx, 1-10. http://dx.doi.org/10.1016/j.hlc.2016.02.016

23. Bryan Williams, Thomas M MacDonald, Steve Morant, David J Webb, Peter Sever, Gordon McInnes, lan Ford, J Kennedy Cruickshank, Mark J Caulfi eld, Jackie Salsbury, Isla Mackenzie, Sandosh Padmanabhan, Morris J Brown, for The British Hypertension Society's PATHWAY Studies Group. 2015

24. Verena Fourkiotis, Oliver Vonend, Sven Diederich, Evelyn Fischer, Katharina Lang, Stephan Endres, Felix Beuschlein, Holger $S$ Willenberg, Lars C Rump, Bruno Allolio, Martin Reincke, Marcus Quinkler and for the Mephisto Study Group. Effectiveness of eplerenone or spironolactone treatment in preserving renal function in primary aldosteronism. European Journal of Endocrinology (2013) 168 75-81. DOI: 10.1530/EJE-12-0631

25. Hitoshi Minakuchi, ShuWakino, Hidenori Urai, Arata Kurokochi, Kazuhiro Hasegawa, Takeshi Kanda, HirobumiTokuyama \& Hiroshi Itoh. The efect of aldosterone and aldosterone blockade on the progression of chronic kidney disease: a randomized placebo-controlled clinical trial. Natureresearch. Scientific reports. 
(2020) 10:16626 https://doi.org/10.1038/ s41598-020-73638-4

26. Murray Epstein,Gordon $H$. Williams, Myron Weinberger, Andrew Lewin, Scott Krause, Robin Mukherjee, Rajiv Patni, and Bruce Beckerman. Selective Aldosterone Blockade with Eplerenone Reduces Albuminuria in Patients with Type 2 Diabetes. 2006 by the American Society of Nephrology. ISSN: 15559041/105-0940

27. Romain Eschalier, M.D. John J.V. McMurray, M.D. Karl Swedberg, M.D., Ph.D. Dirk J. van Veldhuisen, M.D., Ph.D. Henry Krum, M.B., Ph.D. Stuart J. Pocock, Ph.D. Harry Shi, M.S. John Vincent, M.B., Ph.D. Patrick Rossignol, M.D., Ph.D. Faiez Zannad, M.D., Ph.D. Bertram Pitt, M.D. Safety and efficacy of eplerenone in patients at high-risk for hyperkalemia and/or worsening renal function: Analyses of EMPHASIS-HF study subgroups. Journal of the American College of Cardiology. 2013. DOI: 10.1016/j.jacc.2013.04.086

28. Stefan Brunner, MD Sabina P.W. Guenther, MD Korbinian Lackermair, MD Sven Peterss, MD Martin Orban, MD Anne-Laure Boulesteix, PhD Sebastian Michel, MD Jörg Hausleiter, $M D$ *Steffen Massberg, MD Christian Hagl, MD. Estimated Long-Term Survival With Eplerenone. 2019. https://doi.org/10.1016/ j.jacc.2019.02.043

29. Andrew S. Bomback. Mineralocorticoid Receptor Antagonists in End-Stage Renal Disease: Efficacy and Safety. Karger. Review - Advances in CKD 2016. DOI: 10.1159/000441262

30. Matthew J. Volk \& Andrew S. Bomback \& Philip J. Klemmer. Mineralocorticoid Receptor Blockade in Chronic Kidney Disease. Springer Science+Business Media, LLC 2011. DOI 10.1007/s11906-011-0202-2

31. Wenguang Feng, Louis J Dell'Italia, Paul $W$ Sanders. Novel Paradigms of Salt and Hypertension. J Am Soc Nephrol. 2017. DOI: 10.1681/ASN.2016080927

32. Міщенко Л.А., Матова О.О., Шеремет М.Ю., Сербенюк K.І. Порівняльна ефективність спіронолактону, еплеренону, небівололу і моксонідину у хворих на резистентну артеріальну гіпертензію. Український кардіологічний журнал 6/2018. DOI: http:// doi.org/10.31928/1608-635X-2018.6.6571

33. Застосування діуретиків у пацієнтів із артеріальною гіпертензією: перспективи й обмеження. Матюха Лариса Федорівна. Український медичний часопис. УДК 616.12-008.331.1+616-08-035+612.464.1 https://www.umj.com.ua/wp/wp-content/uploads/2016/04/3088.pdf?upload=
34. Lawrence $R$. Krakoff. Diuretics for Hypertension. Circulation. https://doi.org/10.1161/ CIRCULATIONAHA.105.570192

35. MICROZIDE (Hydrochlorothiazide). U.S. Food \& Drug Administration (FDA) https:// www.accessdata.fda.gov/drugsatfda_docs/ label/2011/020504s018lbl.pdf

\section{PEЗЮME}

\section{КЛИНИКО-ФАРМАКОЛОГИЧЕСКИЕ ОСОБЕННОСТИ ИСПОЛЬЗОВАНИЯ АНТАГОНИСТОВ АЛЬДОСТЕРОНА У БОЛЬНЫХ ГИПЕРТОНИЧЕСКОЙ БОЛЕЗНЬЮ}

\author{
Мойсеенко В.А., Бондур В.В., Любицкий А.А. \\ Национальный медицинский университет \\ имени А.А. Богомольца \\ Киев, Украина
}

Введение. Гипертоническая болезнь - часто встречающееся заболевание с тенденцией роста. Она приводит к большому числу морбидных состояний, имеет широкий спектр проявлений и вызывает тяжёлые осложнения. Для борьбы с этой проблемой были разработаны фармакологические препараты для предотвращения прогрессирования и улучшения качества жизни пациентов с гипертонией. Однако для улучшения эпидемиологической ситуации разрабатываются новые препараты с более специфическим та эффективным действием. Безопастность, экономичность и эффективность в использовании препаратов имеют решающее значение при выборе фармакотерапии.

Цель. Сравнить эффективность, безопастность и особенности использования антигипертензивных препаратов спиронолактона и эплеренона.

Материалы и методы. Библиографический - проведен теоретический анализ и осуществлено обобщение данных литературы, проанализировано фактическое содержание. При исследовании использованы анкетно-опросный метод, а также - описание, анализ, реферирование.

Результаты и их обсуждение. Принимая во внимание распространённые заболевания мочевыделительной системы, такие как хроническая болезнь почек и гиперальдостеронизм, а также сердечно-сосудистой системы, как артериальная гипертензия, которые могут быть обременены угрожающими сопутствующими состояниями, более безопасная фармакотерапия достигается при использовании эплеренона. Этот препарат проявляет свою эффективность не только при лечении артериальной гипертензии, а и в случае других заболеваний и состояний, таких как альбуминурия при сахарном диабете II типа, хроническая болезнь почек и гиперальдостеронизм. Фармакокинетические особенности эплеренона наделили его большей специфичностью в блокировании рецепторов минералокортикоидов. А в случае лечения артериальной гипертензии эплеренон не отставал в антигипертензивном эффекте от спиронолактона и имел меньше случаев побочных действий, что делает эплеренон достойным препаратом при лечении вышеупомянутых состояний. 
Выводы. Эплеренон выявил большую безопастность и не меньшую эффективность, по сравнению со спиронолактоном. Это даёт возможность внести эплеренон в линию препаратов при лечении заболеваний, описанных в этой статье.

Ключевые слова: артериальная гипертензия, резистентная артериальная гипертензия, хроническая болезнь почек, скорость клубочковой фильтрации, спиронолактон, эплеренон.

\section{SUMMARY}

\section{CLINICAL AND PHARMACOLOGICAL FEATURES OF THE USE OF ALDOSTERONE ANTAGONISTS IN PATIENTS WITH HYPERTONIC DISEASE}

Moyseyenko V.O., Bondur V.V., Lyubitsky A.A.

Bogomolets National Medical University Kyiv, Ukraine

Introduction. Arterial hypertension is a widely spread disease with a tendency to year-over-year growth. It causes a number of comorbidities, has a great variety of manifestations and leads to life-threatening complications. In order to facilitate the situation, a lot of pharmacological remedies, were invented. Thus, a constantly aggravating disease needs further impovements in drug administration. Efficacy, economy and safety concerns are the most valuable aspects in terms of patient's outcome, that's why they have to be investigated and administered properly to reach the best possible effect.
Goal. Efficacy, specifics and safety concerns comparison of antihypertensive drugs spironolactone and eplerenone.

Materials and methods. Bibliographic - a theoretical analysis is carried out and a generalization of literature data is carried out, the actual content is analyzed. In the study, a questionnaire-survey method was used, as well as description, analysis, abstracting.

Results and discussion. Considering the diseases of urinary system, such as chronic kidney disease and hyperaldosteronism and cardiovascular system, of those, the arterial hypertension, both complicated and not, a greater therapeutic effect was reached in case of eplerenone administration. This drug satisfy the demands of clinicians not just in case of arterial hypertension, but also in case of albuminuria in II type diabetes, chronic kidney disease and hyperaldosteronism. And in terms of arterial hypertension, eplerenone was considered just as effective and more safe, comparing with spironolactone. Pharmacokinetics of eplerenone allow it to be much more specific to mineralocorticoid receptor blockade. With the whole picture realised, eplerenone has a great opportunities to compete with other drugs in treating states and diseases mentioned in this article.

Conclusion. Analyzing plenty of investigations, eplerenone can be recognized more safe and equally effective, comparing with spironolactone.

Key words: arterial hypertension, resistant arterial hypertension, chronic kidney disease, glomerular filtration rate, spironolactone, eplerenone.

АВТОРСЬКА ДОВІДКА

\section{Мойсеєнко Валентина Олексіївна}

Національний медичний університет імені О.О. Богомольця, академік НАН ВО України, д.м.Н., професор

моб.: +380677779249:

E-mail: moyseyenko_vo@ukr.net ORCID ID:0000-0003-1402-6028

\section{Бондур Віталій Вольдемарович}

Національний медичний університет імені О.О. Богомольця,

моб.: +380660373660

E-mail: vitaliy.bondur@gmail.com

\section{Любицький Артем Олександрович}

Національний медичний університет імені О.О. Богомольця

Студент IV курсу Медичного

факультету №2

моб.: +380665828626

E-mail: warban152@gmail.com

\section{Мойсеенко Валентина Алексеевна}

Национальный медицинский университет имени А.А. Богомольца, академик НАН ВО Украины,

д.м.Н., профессор

моб.: +380677779249:

E-mail: moyseyenko_vo@ukr.net ORCID ID:0000-0003-1402-6028

\section{Бондур Виталий Вольдемарович}

Национальный медицинский университет имени А.А. Богомольца, моб .: +380660373660

E-mail: vitaliy.bondur@gmail.com

\section{Любицкий Артем Александрович}

Национальный медицинский университет имени А.А. Богомольца Студент IV курса Медицинского факультета №2 моб.: +380665828626

E-mail: warban152@gmail.com

\section{Moyseyenko Valentyna}

Bogomolets National Medical

University,

$\mathrm{MD}, \mathrm{PhD}$, Professor

mob.: +380677779249:

E-mail: moyseyenko_vo@ukr.net ORCID ID:0000-0003-1402-6028

\section{Bondur Vitaliy}

Bogomolets National

Medical University моб .: +380660373660

E-mail: vitaliy.bondur@gmail.com

\section{Lyubitsky Artem}

Bogomolets National Medical University 4th year student of the Medical Faculty №2 mob .: +380665828626 Email: warban152@gmail.com 